\title{
Of Jane and Manche: Bodies and virginity as agency for narrative discourse
}

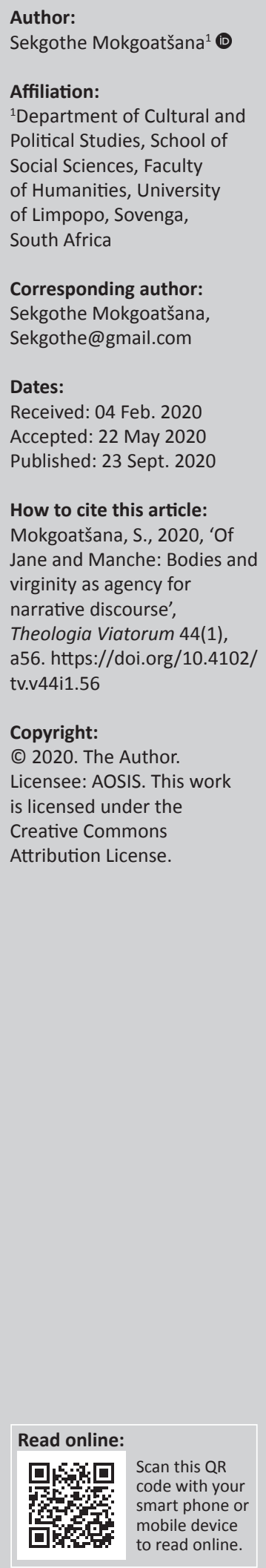

Spivak's rhetorical question 'Can the subaltern speak?' finds true expression in the story of Jane Furse and similarly Manche Masemola dying at the same age as Jane. Two marginal girls are the subject of my discussion, namely Jane Furse and Manche Masemola. The two girls' bodies are employed as agencies to (re)create a religious narrative of proselytising. Both girls do not speak in their voices, but through other bodies who reconstruct the narrative to achieve particular goals. The virgin body is essential to elevate the narrative to a myth. I will argue that the two girls' virginal condition was necessary to construct a discourse that would shape Anglican historiography in the Northern Transvaal. Also, I argue that their marginal condition, subjects them to competing for hermeneutics: firstly, the power of virginity; secondly, the role of the young body to preserve sanctity and transmogrification; and lastly, to begin a debate on the role of young people, especially girls to construct alternative history. I invoke the question of subalternity whether these young people had the power to speak for themselves or they merely become agencies of discourse. I begin my discussion with the Anglican Church's narrative of Jane and then proceed to the story of Manche Masemola to explain how her marginal body was a fit instrument of creating martyrdom and urgency. This discussion is a product of critical inquiry into an oral historical narratives that continues to shape feminine discourse in respect of power, race and inter-subjectivity.

Keywords: virginity; martyrdom; asceticism; narrative discourse; Jane Furse; Manche Masemola; missions; children in missions; subalternity.

\section{Introduction}

Many years ago when I was a teacher at St Marks College in Jane Furse, I stayed in the Priory, an old building that monumentally tells the story of the Anglican mission in Sekhukhuneland. The buildings that had laid abandoned for a long time before 1985 are a constant reminder of the Church's failure to penetrate the local community except for those working in the hospital. Here, the story of Manche Masemola and the 'gift of the Church' was told with fond memories. I had the opportunity to interact with the late Canon Tsebe, married to Manche's cousin. His impeccable command of English, as well as his sublime narratives on Manche, left a lasting memory in my mind. I have since begun a journey through conference papers and publications to explore various aspects of these narratives: from orality, archival records and of late the multiplicity of digital records mushrooming every day. In this article, I draw inspiration from Spivak's rhetorical question 'Can the subaltern speak?' which finds true expression in the story of Jane Furse, a young girl who dies at the age of 14, and similarly Manche Masemola who died ca. 1928 at the same age as Jane. Two marginal girls are the subject of my discussion, namely Jane Furse and Manche Masemola. The two girls' bodies are employed as agencies to create and recreate a religious narrative of proselytising.

Both girls do not speak in their voices, but through other bodies who create and reconstruct the narrative to achieve particular goals. They are used as discursive agencies to tell a story plausible in the hands of the narrator. Instead of listening to their voice, we hear the voice of the narrator who chooses to speak for and represent the girls in a manner that befits the historical time and mission. The narrators deliberately choose a feminine body that has to be a virgin to construct this narrative. The virgin body is essential to elevate the narrative to a myth, that is, a story told to be believed. By telling it as a religious tale, the story becomes sacrosanct and masquerades itself into a historical narrative.

I will argue that the two girls' virginal condition was necessary to construct a discourse that would shape Anglican historiography in the Northern Transvaal. Besides, I argue that their 
marginal condition, as young girls, subjects them to competing for hermeneutics: firstly, the power of virginity; secondly, the role of the young body to preserve sanctity and transmogrification; and lastly, to begin a debate on the role of young people, especially girls to construct alternative history. I also invoke the question of autonomy and subalternity as (re)presented by the two figures, whether these young people had the power to speak for themselves or they merely became agencies of discourse.

I will begin my discussion with the Anglican Church's narrative of Jane Furse to pave a way to penetrate Sekhukhuneland and to leave a lasting memory for both the Church and the Empire. I will then proceed to the story of Manche Masemola as a second narrative developed to create a presence in the Sekhukhuneland country and to explain how her marginal body was a fit instrument of creating martyrdom and urgency. This discussion is a product of critical inquiry into an oral historical narratives that continue to shape feminine discourse in respect of power, race and inter-subjectivity.

\section{Virginity: A definitional challenge}

The institution of virginity is held highly in almost all societies of the world. Traditionally, it involved sexual abstinence before marriage, thus valourising the virginity of the bride as the ideal state to be achieved and maintained at all times. Nagpal and Sathyanarayana (2016:1) explain that Hindu marriage ceremony centres around the kanyādāna [gift of a maiden] ritual which is seen as the gift of a virgin by a father of the maiden through which Hindus believe they gain greatest spiritual merit.

Because of the value attached to virginity, sexual vigilance often replaces sexual responsiveness. The right and will of the individual are often subordinated to the demands of the girl who is guarded and controlled to remain a virgin. Breaking the social code of virginity is abhorred and brings scorn to both the girl who is considered to have committed a sexual offence and her family. The actual male perpetrator is left off the hook and allowed to dupe more virgins into breaking the social code. These social restrictions wear heavily on the female body than on the male body. Virginity, therefore, illuminates the historical and social contexts of the girl's upbringing.

\section{A brief review of Manche Masemola}

The Manche narrative was first collected by an Anglican preacher and teacher Augustine Moeka; however, his notes could not be found in the archives. It is believed that the greatest part of the story is shaped by his notes (Goedhals 2002:101; Masenya 2017:17). Undeniably, Moeka has shaped the discourse around Manche because other than hearing the story from her, and Lucia, he was responsible for translating Lucia's version to Bishop Wilfred Parker in 1937. One central figure who captured the narrative is Mrs Moffat who recorded Manche's death in her diary (Mokgoatšana 2019:15) and in The Cowley Evangelist Magazine (Moffat 1928). In this article, Mrs Moffat argues that Manche's trial was very short, and her death was fit to be considered a case of murder; however, the Church needed to see her as a victim of a murder to declare her a martyr. She goes further to suggest that Manche's death could have been as a result of illness, because she was hospitalised before her death, and her sister Mabule died a few days later. Bishop Parker's interview with Lucia is a dominant primary source that has shaped the Masemola narrative (Parker 1937). All others parody the same work, and at times read into it, for example, the baptism by blood oftentimes is not derived from this source, but a detour which is found favourable to mention as a fact.

Goedhals (1998, 2000) sketches Manche's hagiography contextualising it on the political environment that shaped it. She eloquently points at the friction between the Church and the Bapedi world as a result of fresh memories of the last Bapedi wars with the British. Her work is a ground-breaking study on the life of a martyr who was eventually sanctified and consecrated as a saint. Kuzwayo (2013), a relative of Manche Masemola completed a dissertation exploring how ritual, baptism and koma [initiation] interact and are used to construct Manche's identity. Mokgoatšana (2019) examines the Manche narrative as a myth based on a prophecy that Manche would be baptised in her blood. The article uses William Bascom's definition of a myth, a technical definition in Folklore Studies, to refer to a story told to be believed. These texts explore Manche's life and narrative from contrasting ideologies that shaped the gaze and construction of meaning.

\section{Jane Furse and Manche: Virginal bodies and discursive urgency Jane's (virgin) body}

This section purports to explain how Jane's body is used as an instrument to continue missionary work and expound how her virginity assumed or constructed was also relevant as an important urgency to mediate discourse. In 1921, a missionary hospital was opened in Sekhukhuneland where the seeds of Anglicanism were sown. We are told that the Hospital work began in 1921 (Humphries 1980; Jane Furse Memorial Hospital 1971) with mud huts and 18 beds (Waldmann 1980:48). According to Humphries (1980:144), the hospital opened with 12 patients, and when he visited the hospital again in 1966-67, it had 414 beds and 100 mats for floor patients. At the time of his visit (Humphries 1980:144), the hospital was advanced to train 100 nurses and 12 midwives all with Junior Certificate (equivalent to Grade 10 today) with English endorsement.

The Jane Furse Memorial Hospital report goes on to explain that:

Inspiration to found the Hospital arose from the life, the only child of Bishop Michael Furse and Francis, his wife. A life terminated here on earth in death from scarlet fever on 3rd August 1918, just as Jane's birthday was approaching. 


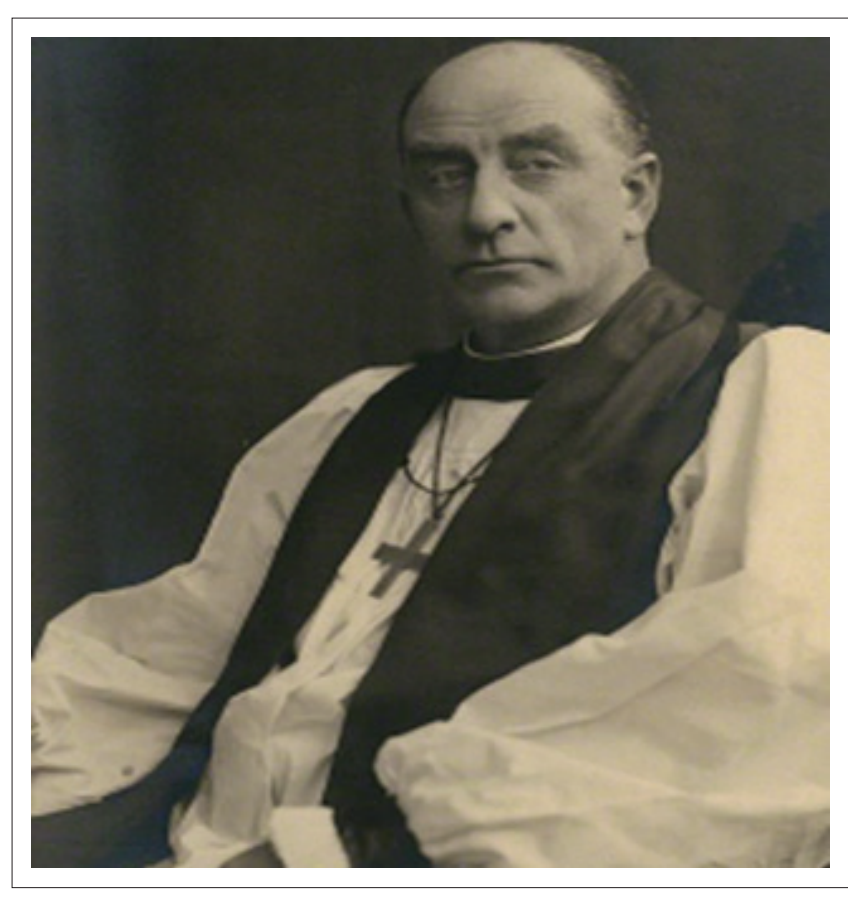

Source: https://en.wikipedia.org/wiki/MichaelFurse

FIGURE 1: Michael Bolton Furse.

But the love and concern she engendered lives on. Throughout the years the hospital has grown and its usefulness increased, despite setbacks, now until now it has 416 authorised beds, 100 sleeping mats and a large outpatient and clinical commitments. (Jane Furse Memorial Hospital 1921-1971:7)

This extract derives from the 50 years' celebration of the existence of Jane Furse Memorial Hospital in 1971. 'Jane' became a central focus of the memorialisation. This hospital was named Jane Furse Memorial Hospital in honour of the Bishop's daughter, Jane. Jane Diana Furse was an only child of Bishop Michael Bolton Furse of Oxford in the United Kingdom and Frances Furse from the United States (http:/ / historicalpapers-atom.wits.ac.za/c1-1-3). Michael Bolton Furse was the Archdeacon of Johannesburg (1903-1909 and later the Bishop of Pretoria (1909-1920). Bishop Micahel Bolton Furse was born on 12 October 1870 at the end of the Franco-Prussian War in Staines, Middlesex, United Kingdom. He was the son of Reverand Canbon Charles Wellington Furse and Jane Diana Johnson Furse. He had several brothers and sisters including John Henry Monsell Furse and Elizabeth Dia Maud. In 1903, he moved to South Africa and was consecrated as the Bishop of Pretoria in 1909. Michael Bolton Furse and his wife were buried in a churchyard at Cuddesdon just outside Oxford.

Jane was born on 19 August 1904 and died of scarlet fever in 1918. She is buried in the cemetery at Irene, Gauteng (http://historicalpapers-atom.wits.ac.za/c1-1-3; http:// www.historicalpapers.wits.ac.za/? inventory/U/ collections\&c=AB3168/R/7665). When her father was consecrated the Bishop of the Diocese of Pretoria, she would accompany him on his trips. It is at these trips that she became sorrowfully aware of the squalor and abject poverty of the hinterland. Jane died at the end of the First World War

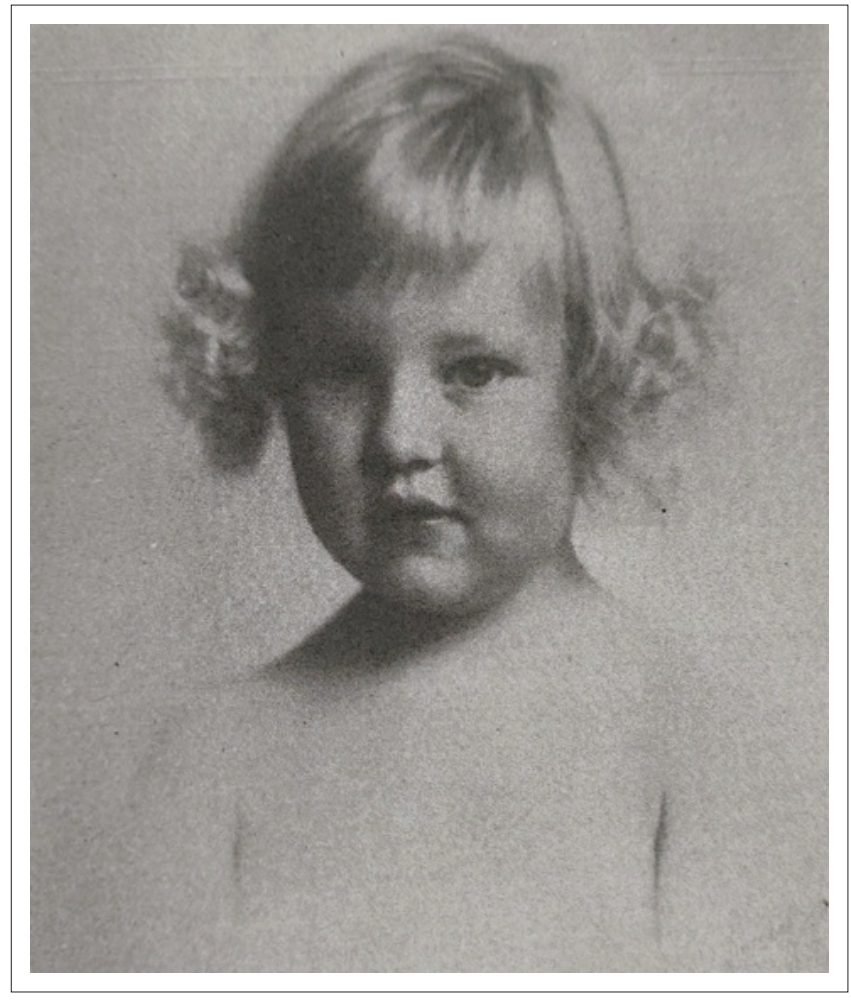

Source: Photo by Sister Betty Thorburn, O.H.P. in Jubilee Edition, 1921-1971 FIGURE 2: Jane Furse.

when Britain made a call to all young men to respond to their country's needs for the army, and young women also were ready to offer their services as nurses in the army (Watson 1997). Watson (1997) further quotes an interaction of the Beale family where the sisters argue that there is nothing a woman could help her country more in doing than to mending its men. This view was considered right at the time as nursing was considered an innate gift of a woman than it is viewed today. Surely, views about women in this era were very negative about women, and their possible participation in such professions as nursing and medicine. Watson (2002:489) clearly puts it that Medical women had to prove their competence in a male-dominated field to a genderdivided society and ironically found an opportunity to do so in a period dominated by images of masculinity. Furthermore, nurses had to prove that their craft was professional. Had Jane not died at this time, young as she was, she would have joined the medical mission in Jane Furse where her father's Bishophry extended. Here it would be inevitable not to join the Daughters of Mary who occupied the epicentre of mission operations and education at the time.

When the Anglican Church established the hospital in the 1920s, it was named in her memory as Jane Furse Memorial Hospital. Jane Furse is in the centre of Sekhukhune Municipality, which had always been the heartland of Sekhukhuneland, which served as the nerve cord of Bapedi polity in Gelukslokasie. My interest in this matter is how the Anglican Church claims and renames topographical space as a marker for political authority, claiming space for the British empire. Descending from Oxford, he found it fit to expand 
the horizons of the imperial centre. Naming the hospital into Jane is consonant with Anglican practices of intercessions connected with the Virgin Mary. Although Kuzwayo (2013:57) claims saints and important figures in the church were not worshipped, her assertion that it is also our prerogative to state that they are honoured as notable members of the Christian family as Christian ancestors with whom there is still unity through a living fellowship with Christ suggests that as ancestors they are connected with the living, invoked in times of need. This matter she further accentuates by quoting Tlhagale (2000:2) laboriously that these individuals are elevated to the spiritual realm, possessing spiritual power, believed to derive them from their close communion with God. With her name immortalised through memorial discourse, Jane's name is invoked inside and outside church circles. This has become apparent since the new hospital was opened, leaving the old buildings to the church's control. What is worrisome, however, is the possible loss of historical memory connected with the old Jane Furse Memorial Hospital. Firstly, the concept of 'memorial' seems to be lost in the naming of the hospital as can be seen on the signboards, and secondly, the names of wards such as Lugsden, Blake, St Manche, Darras and many of these historical names are nowhere to be found in the 'new' hospital. Interestingly, the revamped hospital is popularly called the new hospital, which finds expression in the seminal loss of its roots and identity from the old hospital as I outlined.

Jane's narrative is imbued with a philanthropic zealousness. This is what is described in the 1971 Jubilee as 'love and concern'. Her body has become the first vehicle to explain the salvation escapade and triumph over darkness. Her story is an eschatological exposition of the coming of a new, and the destruction of an African world characterised by what the West describes as primitive, animistic and backward. Her body represents the 'new light' and the very incarnation of the story of salvation and civilisation. Her short life is extended through memory to tell a story of salvation and relief. She is used as an inspiration to help the poor and the needy through the medical mission. The tale of a 'white girl' drawn to convert African souls seemed incomprehensible to the intended audience. First, she was unknown and would not inspire confidence and the vital force to attract Bapedi communities into the new faith.

I also think the whole memorialisation of Jane Furse was an attempt to deal with the loss of a daughter. Having buried her daughter, within 2 years the Bishop was entrusted with a new task of establishing a medical mission hospital in Sekhukhuneland. The memory of her fallen daughter was fresh and too much to bear. Naming became an easy route to 'immortalise' and re-locate her spirit in a manner that it would be transmogrified and live forever in a boundless world populated by Anglican subjects.

From the onset, the institution was seen as a memorial site. As a memorial site, the hospital became a site for defining imperial order and an instrument for laying the ground for missionary work in Sekhukhuneland. The Church deliberately chose Jane's body as an instrument to evangelise and rally support for missionary work outside England. It was important to choose a blameless, virgin body to project a zeal to do philanthropic work. The virginal condition has a social, political and theological function in Christian circles. Virginal discourse should be understood for its fluidity and flexibility.

The virgin body is a site of defining not only social honour but an aspired condition to be pursued. A virgin body is a representation of the ideal, a condition that needs to be attained and fought for. It is a battle between bodily desires and the spirit the feminine body is regulated to keep it pure. This desire for purity is rooted in Christian history. A virgin is an ideal woman, a figure that represents a victory against passion. Whether Jane's virginity was constructed or merely a product of chance remains debateable; however, the condition was important in the era when the Daughters of Mary were required to serve as models for the catechumens. Upon establishing the hospital and the chapel, young maidens were recruited to join the Daughters of Mary, coming through the Wayfarers, to which Manche was also attracted.

Jane's body has become synonymous with the hospital. In most writings, reference is made of Jane, when actually, they referred to the hospital. Jane, therefore, has become the metaphor to expand memory and reference. The Jane Furse Memorial Hospital Report of the Sekhukhuniland Missions of the period 01 April 1954 to 31 March 1955 in the Foreword by Robert Pretor dedicates a special memory to the death of Bishop Furse, Jane's father, with these words (Jane Furse Memorial Hospital 1971:3):

For though 'Jane' was started after Bishop Furse left Pretoria, it was largely his enthusiasm and the funds which he raised through some long lean years which have maintained it. So Jane Furse Hospital witnesses not only as a memorial to his daughter but also to a great Bishop.

In terms of this view, Jane's death was played forward in recognition of her father's missionary work in the Northern Transvaal. Jane's memory is invoked to present her father's legendary work, and sacrifice to work against the odds in the difficult environmental conditions of Sekhukhuneland. This memory was used not only to raise funds for the medical mission hospital but also to continue philanthropic work which is explained briefly by Prof Erasmus quoting Jane - $A$ Memoir: 'In a letter to a friend, written from Sabie a few weeks before she died, Jane said that she had been trying to think out why there was so much sickness and suffering in the world, and she had come to the conclusion that it was not God's will, and that it need not be, and that we ought to do all we could to fight it. Therefore she had decided to do her part by becoming a doctor'.

Her desire to rid the world of suffering and sickness is noble and well-meaning; however, most of the suffering was a result of imperialist dehumanisation of the world through 
plundering the economies of the colonised states. This is adumbrated by Nkomazana and Setume (2016:51) who opine:

The export economy established by Europeans meant that Africans extracted raw materials while Europeans returned manufactured goods. The trade, which was oriented toward the west, advantaged Europeans at the expense of the indigenous populations.

The devastation of the colonised lives was a planned colonial enterprise, and it was furthered in the same vein during the apartheid years. The Jane Furse Hospital was not immune from the apartheid segregationist policies of inferiorisation. At the 50th anniversary of the hospital, Mr Viljoen, speaking on behalf of the Department of Bantu Administration (Jane Furse Memorial Hospital 1971:16) without mincing his words tells the organisers of the event that:

In as far as the progress of the Bantu is concerned, I feel that you have had great success. It was pointed to me that you employ 290 Bantu in various posts while only 15 whites are employed. As you know it is the policy of the Government that the Bantu should serve his people. To achieve this, the Bantu must be trained to fulfill a task. This is not an easy task because Bantu with the necessary qualifications not always forthcoming. I must point out, however, that every effort should be made to find suitably qualified for appointment in the various posts so that hospitals will eventually be manned by Bantu exclusively.

Although the hospital was established by the church, lack of funds pushed it towards the segregationist apartheid government for support.

The Right Reverend E. Knapp-Fischer, Bishop of Pretoria attributes the growth and development of the hospital to Jane's memory (Jane Furse Memorial Hospital 1971:13):

We look back with thanksgiving to the blessings so abundantly bestowed on Jane Furse in the fifty years. We look back with deep gratitude to our founder Bishop Michael Furse, and to his only daughter who gave her name to this hospital. Jane lived but a short time in this world.

The Bishop goes on to appeal to the audience not to 'sorrow for her premature passing' but 'rejoice in faith of the Risen Christ', because 'Jane continues her great work and witness which only began during her short earthly life' (Jane Furse Memorial Hospital 1971:13). In this celebration, speaker after speaker, Jane's short life is employed as a narrative urgency to express thanks to the father's dedication to the bishopric work. Her spirit is linked with the growth and development of the hospital. Her short life compares squarely with that of Manche Masemola. Manche died before the Easter, a time earmarked for her baptism, whilst Jane died a week before celebrating her birthday. Manche's deep desire to be baptised could not be achieved, although considered to be baptised by her desire. Similarly, Jane did not live to see her vision as the Matron of the Jane Furse hospital explains in 1956:

Hanging in the entrance hall is a beautiful portrait of 'Jane' which will be a continual reminder to the staff and visitors of the true purpose and dedication of the hospital, 'to serve the African peoples', as was once her childhood vision. (Jane Furse Memorial Hospital 1956:11)

Her hanging picture is a constant reminder of her vision and visual representation to instil discipline amongst staff and the Christian community of the burning desire to help the poor, thus inspiring confidence and commitment.

That she was an only child is important to consider in the recontextualisation of the Jane Furse story. Like many special children in the Bible like Isaac and Jesus, Jane is chosen as an allegory to explain offering and sacrifice. She is the only daughter of Bishop Furse who could not live to see the missionary dreams of her father. She is described as a 'blessing' that had given her name to the hospital. The hospital is therefore seen as an incarnation of her spirit. It is no surprise therefore that it is affectionately described and referred affectionately as 'Jane' in most correspondences and deictic references.

Having succumbed to scarlet fever, she is still considered a philanthropist, whose work would continue to inspire those coming after her. In his concluding remarks, Bishop Knapp-Fisher (Jane Furse Memorial Hospital 1971:14) maintains that:

[T] he work and witness of Jane will go forward and continue to grow provided that those who are serving it now with such dedication are succeeded by men and women who are prepared to follow in their footsteps.

Jane has thus become not only a torchbearer for future work at Jane Furse Memorial Hospital but the springboard on which future medical missions should grow. This monopoly, of responsible ministry to suffering, was solely in the hands of the Church in the time in question. As Reverend SelbyTaylor, the Archbishop of Cape Town puts it, 'the Christian Church was the sole instrument of active and informed compassion in the context of human misery, disease, and squalor' (Jane Furse Memorial Hospital 1971:18). That Jane died of scarlet fever gave impetus to the hospital's pursuit of the medical mission, as a result, 'Jane's influence spreads far and wide' as noted by Reverend Selby-Taylor in 1971.

The Jane story was used as a rallying voice to attract support from England and other parts of the world to finance the course of the Church. Jane's name could not succeed to influence local communities into accepting her philanthropic enthusiasm. As a result, a new ploy was necessary to conquer the difficult Bapedi country and their cosmologies.

\section{Manche's virgin body}

Manche Masemola was born ca. 1913 in GaMarishane, about $15 \mathrm{~km}$, away from the Anglican Priory, in Jane Furse, Sekhukhuneland. In 1919, Augustine Moeka, an African Priest of the Anglican Church established the St Peters Church in this village. Manche and her peers were attracted to the Church and started attending catechumen classes to be baptised. Manche, like most local children, received resistance 
from her parents because of the diametrically different religious worldviews, namely that of the Bapedi and the Church (representing English values). The latter was seen by her parents as being antithetical to the traditional religious beliefs they so dearly upheld and practiced. The tensions between the English and Bapedi had not been fully settled following the Sekhukhune wars. The Church's perceived condescending attitude towards African beliefs and rituals also increased the tension. In terms of her culture, Manche was to marry her cousin. To do this, she had to undergo an initiation (koma), which is central to Bapedi nurturing and socialising boys and girls to adulthood. When Manche rejected the prospect of marriage with her cousin, as a demonstration of her devotion to the Anglican teachings, her parents felt they had lost their child to strangers. So, further beatings happened which may have possibly led to her death. Kuzwayo (2013:iii) explains why there was tension between Manche, here symbolising the Church, and her parents, representing Bapedi culture:

According to Pedi custom, a girl was supposed to eventually get married after she had been proclaimed marriageable. Manche's parents were not happy when she joined the Church, as there were nuns in the village, who had made vows of remaining celibate and only be married to Jesus Christ. The presence of nuns suggested to them that Manche might want to be one of them ...

Kuzwayo (2013:43) extends this opinion by proving that the local community was threatened by the missionaries, who advised against circumcision and marriage to convert the girls to become nuns, whilst their parents wanted marriage and lobola. The same idea is expressed by Goedhals (1998:37) who proclaims that Manche's mother may have feared that Manche would ultimately join a celibate sisterhood. First cousin marriages are desirable and preferred amongst the Bapedi. Following this custom, Manche was engaged to her cousin who was working in the town. In an interview with Parker (1937:2), Lucia explains that Manche would not wait for the 'boy' to come home; unfortunately, when he came, she was already dead. It is evident from this interview that had she lived to be baptised, she would not have married her cousin, whose name is not mentioned in the interview. This would not necessarily be Manche's choice, but the church's will to destroy African customs and traditions as explained before.

Manche, who died at the age of 14 , had contact with the Church for only a year, 1927-1928. Her attraction to the Church and her exploits to resist renouncing her culture is a story that the Church treats fleetingly. The power of her story lies in her death which is graphically described to graft a martyr out of her body.

Interestingly, both girls have their stories told after their death. We are denied the full context of their calling, and how they would have reacted to the stories if they had lived enough to witness the renditions of their lives as texts. Death of the body is used as a medium to explain deeper religious convictions and dreams. This article will, therefore, use the stories of Jane Furse and Manche Masemola as sites of defining religious martyrdom, and as a proxy for Anglican beliefs for salvation and religious imperialism. It is Jane's soul and body that the Anglican Church first uses to follow a 'dream' to build a lasting memory in Sekhukhuneland. Then, is the body of Manche Masemola that is subjected to violent, brutal attacks and persecution that is used to create a model for accepting faith and pay the ultimate price.

Both Jane and Manche died at the age of 14 under difficult circumstances. Jane was overcome by scarlet fever whilst Manche suffers persecution and dies in the hands of her parents. The two teenagers lived lives of an ascetic. As ascetics, their stories pursue hagiographical fervour to recreate a symbol of ideal Christian perfection and angelic life. The two virginal narratives centralise asceticism and renunciation as common themes. Castelli (1986:61) contends that feminists explain asceticism and renunciation as a paradoxical renunciation of the world constraining women's social and political power, and experiencing a sense of worth outside the traditional setting of marriage. In essence, a Christian virgin is considered engaged and married to God. This interpretation of virginity is defined better in Mariology. Following the biblical Mary's virginity as a symbol, virginity is seen in the context of salvation. To follow Mary is to pursue salvation and to be accorded special status in the Kingdom of God.

Because of their virginity, both Manche and Jane are 'highly exalted', considered above all women and the entire human race (Pigg 1999:111). Their lives influenced commentary and liturgical services. The two girls: Manche and Jane Furse have become the subject of Anglican historiography and pilgrimage. Their virgin bodies are figures of veneration. In Marian thought, the body is privileged as a material site. In terms of that view, the virgin Mary's body is a site of generation, a body from which Jesus grew. This semiology works better to ensure that both Jane and Manche achieve sexual and spiritual purity.

Whereas Jane is not consciously and purposefully celebrated like Manche is, she is continually memorialised through toponymy. The name of the hospital and by extension the area around the hospital have become synonymous with her. Today Jane Furse is not only Bishop Furse's daughter, or the memorial hospital, but extended to include a collection of villages further away from the hospital. Besides, Jane Furse has become a fast developing town in Makhuduthamaga Municipality.

Jane's virgin body is an instrument to narrativise and construct a discourse to negotiate entry into Sekhukhuneland. It speaks of the coming of a new faith in a foreign land, and this exploration is metaphorised in her death. Jane became a symbol of religious purity and the pursuit of a perfect relationship with her Maker. As soon as the hospital was established, a chapel was opened in the hospital. Here, Jane's spirit and a dream were realised by sowing the seeds of the Daughters of Mary who became visible markers of episcopal 
prestige. She was a product of the Bishop's ascetic agenda to craft a portrait of Christian followers. She is used as a pawn to re-enact and embody 'baptism' and confession. She is used as a proxy for her father's commitment to missionary work.

Jane's body localises the power of the father and the Church. Through its virginal condition, the Church continues its missionary work to save the poor and ultimately convert them. The Jane Furse Memorial Hospital is established to fulfill that mission through medical service. Her life is deliberately constructed to fulfill this role. To do this well, she has to be prepared to enter the league of the Daughters of Mary. Daughters of Mary took an oath of celibacy and renunciation. As explained elsewhere in this article, had Jane survived the fever, she would have lived with the father in the priory where the Daughters of Mary found a home too. Here, their focus was to use the Wayfarers as instruments to attract young girls into the ministry. It was their presence and teachings of the time that threatened Manche's parents to the extent that they would not allow her to be lost to the church.

\section{Death and absence}

Death is a common narrative for commemoration. In this article, Manche and Jane are remembered using death as a trope to recover and reconnect with their lives. Jane, whose body and spirit are connected to Jane Furse Memorial Hospital, became a symbol for the hardships that the Church would face in the new environment. She represents a journey, a battle to conquer African cosmologies and replace them with Christian, Anglican theology.

It is not surprising that Manche is celebrated and memorialised. She suffered brutal persecution that led to her eventual death. Her life is celebrated annually. Her grave has become a shrine where congregants meet to mourn, celebrate and pay homage to a heroine whose life paid an ultimate price. Her absence is a marker for the loss and epistolary journey of a Christian martyr.

Manche and Jane Furse's bodies are celebrated and commemorated to promote imperial and religious interests. Jane's body is memorialised and re-membered. This is first done by naming the hospital after her. Her story is a narrative of bodily suffering. Jane's body succumbed to scarlet fever and buried her dreams. This invocation of her psyche is foregrounded to strengthen the missionary zeal of her father and the Church in general. Her dream of helping the poor became an anchor to support the Church's exploits and adventures into the unknown, unsafe territories. In this uncharted and 'uncivilised' world, the Church needed to plant the seeds of salvation. Her commemorated spirit becomes a driving force to encourage the weary and strengthen missionary work in Sekhukhuneland. Besides, her spirit would fill new converts and expand philanthropic work. In the words of The Right Reverend E. Knapp-Fisher who was the Bishop of Pretoria during the 50th celebration of the hospital's existence, he says:

We share the sure hope of resurrection. In the life and growth of this hospital, we can see that Jane continues the great work and witness which began during her short earthly life.

As a 'witness', Jane's life is fit to be an exemplary model for self-sacrifice and dedication to the life of the poor. The growth of the hospital was understood as a metaphorical representation of Jane's life embodied in the concept of 'resurrection' which features prominently during the celebration. Besides, the mission hospital expanded its medical mission through the establishment of clinics. It was the staff from Jane Furse Memorial Hospital who went on to build and consecrate new clinics as Dr C.S. Harrison did at Manganeng. In his speech, the Most Reverend R SelbyTaylor, the Archbishop of Cape Town acknowledges the expanse of the mission (Jane Furse Memorial Hospital 1971:18).

Her virginal status is constructed and imposed. Her condition is relevant to spread the Word in Africa and to use her as a model to follow. Like most hagiographies, her chronicle is defined according to patronymics or matronymics. She is no ordinary girl from an English background, but the daughter of the renowned Bishop Michael Bolton Furse, an eminent Anglican bishop in the first half of the 20th century. Furse was the fourth son of Ven. Charles Furse, Archdeacon of Westminster, and Jane Diana Monsell, second daughter of John Samuel Bewley Monsell, vicar of Egham. Jane's name invokes the history and ancestry of the Furse family together with the exploits of the Anglican Church in the Northern Transvaal.

\section{Asceticism and martyrdom?}

Asceticism is a lifestyle characterised by abstinence from sensual pleasures, often to pursue spiritual goals. The highest prize of asceticism is oftentimes martyrdom, an institution highly held in the Church. Mokgoatšana (2019:3) tellingly describes a martyr in this way:

The Greek word refers to a witness, a testimony, yet in Christian mythology like in the New Testament, it acquired a new shade of meaning to refer to the testimony about Jesus. The English word is considered a transliteration of the Greek concept. A martyr henceforth refers to someone who suffers a penalty for his or her faith and has to be a witness until his or her death. Martyrs suffer persecution and death for advocating, renouncing, refusing to renounce, or refusing to advocate a belief or cause as demanded by an external party, including society at large. To be a martyr, therefore, one has to profess a faith and defend it even if it means paying a heavy price - death.

There is a strong relationship between martyrdom and asceticism. Martyrdom was a great feature of the early persecution of Christians, where people committed to their faith would pay an ultimate price in defence of their faith. Once the prosecution of Christians declined, a new form of martyrdom emerged in the form of asceticism. It is for this 
reason that Castelli (1986:66) opines that martyrdom precedes asceticism. He traces how the ideology of asceticism made it possible for the faithful to follow Christ and achieve perfection during persecution without being martyrs. Asceticism became elevated and honoured than martyrdom. In this way, new notions of the 'non-bloody' martyrdom of renunciation were developed. This era ushered in the special status of virgins, a new narrative that proclaims that 'marriage is good, but virginity is better' (Castelli 1986). This explains better how the pains of marriage subjugate the subjectivity of the individual, thus undermining virginity. Virginity, therefore, becomes defined about concerning marriage other than in the personal choice of an individual to abstain and renounce desire.

Unlike Jane, Manche's marriage was destined to happen in terms of cultural protocol. She was supposed to marry her cousin. The Church fought fiercely to stop her from following her cultural rituals such as koma and marrying her cousin. This should be understood against its pursuit to destroy African cosmologies and replacement by European belief systems and culture. She has to renounce her culture in favour of outsider culture. The marriage with the cousin would interfere with her virginity, something that as a conscript for the Virgin Mary she would have to renounce. In the eyes of the Church, Manche needed to preserve her chastity because she would be married to Christ. Hodgson (2003:145) notes this tension when writing about the challenge of interpreting Manche's martyrdom:

The concept of a virgin martyr is problematic. The cult of virginity reflects the Judaeo-Christian understanding of sexuality that, in both Protestantism and Catholicism, fails to discern the fine line between carnal and incarnational, thus equating sex with sin. This stance excludes a major component of African spirituality: namely the celebration of the body, feelings, and relationships as fitting contexts for encounter with God.

The Church however privileges the notion of virginity in representing Manche's martyrdom. Her virginity receives prominences, such that her martyrdom become elevated and accentuated.

Her body becomes the site of struggle to protect her autonomy to make decisions about her faith and culture. Her commitment to African culture and values is silenced, and renunciation of own culture is inscribed and exaggerated. Incredibly, a 14-year-old can be prepared to die for a set of belief systems of a foreign nation which she has had contact with, for just a year or less. Manche's life, therefore, represents the tension between two worlds, and the African world and the imperial western world. She is a captive of the foreign religion whose aim is to completely erase her African life. Like all palimpsests, the tissue of African life can never be completely erased or glossed over. It is for this reason that Manche refuses to baptise in foreign clothing and declare that she will be baptised in her blood (Mokgoatšana 2019). This expression is twisted and juxtaposed as a statement of faith, a commitment to the new religion. Commentators choose to ignore Manche's determination to stick to her culture, keeping true to it. I need to quote from the original here to show that baptism in 'own blood' though said by Manche should be understood in the context of her argument with Moeka:

The priest said to Manche 'Should I not baptize you?' (Manche had been in the hearer's classes for about a year). She said 'I shall be baptized in my own blood'[sic]. (Parker 1937)

The same evidence is advanced by Kuzwayo (2013:52), when she says:

Manche retorted to the idea of western clothing citing her wish to stick to her traditional Pedi dress. That was when Moeka openly told her that she would not be baptised, to which she answered, 'Then I will be baptised with my own blood!'.

I find that this dialogue is interpreted out of context, asserting that Manche's response was to her parents who barred her from becoming a Christian. Manche creates a platform for us to consider religious pluralism when faced with a choice of a multiplicity of religious choices.

Commentators construct the Manche narrative as a story of a martyr who is subjected to inhumane terror and persecution (Goedhals 2000; Kuzwayo 2013; Moffat 1928; Parker 1937). Her mother is the devil incarnation who brandishes very dangerous weapons and fire to subject her to submission of authority. In contrast, Manche is portrayed as a model for salvation whose death represents a victory against evil. That parents and the whole community could be so cruel and become accomplices in such gruesome acts is difficult to fathom. Her body is a theatre of conflicting epistemologies and theology. On the one hand, she is an Africanist who resists foreign domination, whilst on the other hand, she is seen as a victim of community and family pressure.

The Manche and Jane narrative has interesting coincidences that seem to suggest that the narrative is a seamless text woven together to construct a particular discourse. Firstly, it is the fact that both girls die prematurely at the age of 14; secondly, that each dies some days before birthday celebration or baptism and/or Easter; thirdly, that both girls die before their dreams are realised; and finally, that there is a coincidence in terms of celebrating Manche's life in August, the month on which Jane Furse died. Whilst it is believed that Manche died on 04 February 1928 (Goedhals 1998, 2000, 2002; Kuzwayo 2013; Moffat 1928; Mokgoatšana 2019), her pilgrimage is only celebrated in August, coincidentally a few days before Jane Furse's date of death. The Church seems to wield its power in controlling the memory of both girls, determining who to memorialise, how to commemorate and when such a commemoration should happen. Lifshitz (1996:30) speaks at length of how those who have power memory can determine how memory is remembered, and use that power to generate power of the shrine as a source of political power:

Human behavior and decisions are often heavily influenced by beliefs concerning what has happened in the 'past'. Therefore, control over representations of the past can be a source of great 
influence in society. Furthermore, when the medium for representation of the past is the shrine tomb of a deceased saint, the person who controls the monument benefits from an additional source of power, in that holy corpses have been widely perceived as instrumental in the production of miracles.

The Church uses the 'shrine tomb' of the deceased saint; Manche Masemola to control the monument and the celebrations. By right, Manche's life should be celebrated either on her date of birth or death. That her death is shrouded in mystery, at least her date of death has a consensus in the Church. My further concern is why is Jane seemingly celebrated indirectly by using Manche's life and yet invoking Jane's persona by connecting with her date of death. It follows on my assumption that the Jane and Manche story is a seamless narrative to conquer the Bapedi world and religion. There is no formal justification why the pilgrimage and commemoration happen in August and not February, although Mr. Chosahane's view is that the commemoration is 'usually held in August instead of February, because of wet weather conditions in Limpopo' (Kuzwayo 2013).

\section{Conclusion}

The masculine speaks for the feminine and constructs meaning using the female body, thus locating women as passive participants in the historical narrative they create. They are denied a voice and have to contend with historical representations of time and voice through death and absence.

The Jane Furse and Manche Masemola narratives are discursive agencies to plant the seeds of Christianity in Sekhukhuneland. Both tales are employed as a proxy for the colonial hand that wished to recognise through religion, dominate and subvert local cultures. The Jane narrative fails to have the power to convert Africans, despite its extension in using the medical mission. Jane Furse Memorial Hospital was part of the grand scheme of converting people into Christianity. It was in the hospital where all mission services were conducted. It began with a chapel that punctuates the religious philosophy guiding the medical mission, the training school for nurses, children's wards which doubled up as an elementary school, especially St Nicholas and St Manche wards. The Manche narrative of resistance and martyrdom was an alibi of the failed narrative of Jane. Following this analysis, Manche Masemola seems to be an extension of Jane Furse, thus becoming Jane's alter ego. Because virginity is an instrument to create and shape discourse, both girls happened to be virgins to explain better the mission story of evangelising traditional communities. Of interest is how beyond virginity, the female body was a necessary instrument to name and invoke to expand the church's power of influence. Even after a century, Mmashadi, a popular indigenous name is dominated by the public memory of Jane than Manche. Manche's narrative is less known in Jane Furse outside the church.

I do not find the coincidences of age, celebration and vision of the two girls coincidental but part of the grand plan of a civilising mission. Manche's celebrations in August happen exactly in the week when Jane died. Is it by coincidence that Manche is not celebrated in February, coinciding with her death date, but August? As explained, this seemed to be part of that strategy not to forget the Jane visioning escapades.

This study proposes that future study directions into mission history should begin to understand the role of children in crafting historical discourse. Such studies would inevitably account for how children's stories are told and represented, and explore how such narrations liberate or stifle their voices in the moment of rendition and interpretation. In addition, future studies may out of interest, examine how memories of the past are plausible in the hands of those who create such memories and later beneficiaries of memory.

\section{Acknowledgements}

The author thanks the University of Limpopo Faculty Spring Lectures for providing staff retreat for the completion of this work.

\section{Competing interests}

The author has declared that no competing interest exists.

\section{Authors' contributions}

S.M is the sole author of this article.

\section{Ethical consideration}

This article followed all ethical standards for carrying out research without direct contact with human or animal subjects.

\section{Funding information}

This research received no specific grant from any agency in the public, commercial, or not-for-profit sectors.

\section{Data availability statement}

Data sharing is not applicable to this article as no new data were created or analysed in this study.

\section{Disclaimer}

The views and opinions expressed in this article are those of the author and do not necessarily reflect the official policy or position of any affiliated agency of the author.

\section{References}

Castelli, E., 1986, 'Virginity and it's meaning for women's sexuality in Early Christianity', Journal of Feminist Studies in Religion 2(1), 63.

Goedhals, M., 1998, 'Imperialism, mission, and conversion: Manche Masemola of Sekhukhuneland', in A. Chandler (ed.), Terrible alternative: Christian Martyrdom in the 20th century, Continuum International Publishing Group, Limited.

Goedhals, M., 2000, 'Colonialism, culture, Christianity and the struggle for selfhood: Manche Masemola of Sekhukhuneland, c.1913-1928', Alternation 7(2), 99-112. 
Goedhals, M., 2002, 'A pair of carved saints', Studia Historiae Ecclesiasticae XXVIII(1), 25-53.

Hodgson, J., 2003, "Stones the builders rejected": Ecclesial communities of theexcluded in the Anglican Church in Southern Africa', Missionalia, 31(1) 117-155.

Humphries, S.V., 1980, 'A mission hospital in Sekhukhuneland', The Central African Journal of Medicine.

Jane Furse Memorial Hospital, 1971, Jubilee 1921-1971. Report of the Jane Furse Memorial Hospital and the Sekhukhuneland Mission for the Period 1921-1971 Caxton, Pretoria.

Kuzwayo, M., 2013, 'A Church and culture exploration of the Ga-Marishane village rite of initiation in contestation with the Anglican initiation rite of baptism of adults: A Manche Masemola case study', Master's Degree in Biblical and Historica Studies, University of KwaZulu-Natal, Durban, viewed 10 February 2019, from http://hdl.handle.net/10413/11215.

Lifshitz, F., 1996, 'The martyr, the tomb, and the matron: Gendering the past, 313 794', Medieval Feminist Newsletter 21, viewed 15 December 2018, from https:// ir.uiowa.edu/cgi.

Masenya, M., 2017, 'Manche Masemola and Albert Luthuli: Iconic figures of South African Christianity', Journal of African Christian Biography 2(4), 17-29.

Moffat, G.N., 1928, 'The seed of the church. A true story from the Sekhukhuniland Mission, Transvaal', The Cowley the Evangelist Magazine, November, 249-251.

Mokgoatšana, S., 2019, 'Of prophecy, mythmaking, and martyrdom in Manche Masemola narrative: I will be baptised in my blood', Studia Historiae Ecslesticae 45(2).
Nagpal, M. \& Sathyanarayana, T.S., 2016, 'Virginity - An update on uncharted territory', Reproductive System and Sexual Disorder: Current Research 5(2). https://doi.org/10.4172/2161-038X.1000178

Nkomazana, F. \& Setume, S.D., 2016, 'Missionary colonial mentality and the expansion of Christianity in Bechuanaland Protectorate, 1800 to 1900', Journal for the Study of Religion 29(2).

Parker, W., 1937, 1883-1966 (Bp. of Pretoria 1933-1950), The death of Manche Manche Masemola, 2I.Ts. AB393f. Wits Historical Papers. [A1][A2].

Pigg, D.F., 1999, Representing the gendered discourse of power: The Virgin Mary in Christ I, Papers in parentheses: Medieval Studies. Vol 1., viewed n.d., from https:// www.yorku.ca/inpar/PMS.html

Thagale, B., 2000, The inculturation debate: A South African perspective, Patrick Ryan, Nairobi

University of the Witwatersrand, Historical Papers Archive, viewed 23 March 2020, from http://www.historicalpapers.wits.ac.za/?inventory/U/collections\&c=AB3168/ $\mathrm{R} / 7665$.

Watson, J.S.K., 1997, 'Khaki girls, VADs, and Tommy's sisters: Gender and class in First World War Britain', The International History Review 19(1), 32-51, viewed 12 March 2020, from www.jstor.org/stable/40108082.

Watson, J.S.K., 2002, 'Wars in the wards: The social construction of medical work in First World War Britain', Journal of British Studies 41(4), 484-510, viewed 12 March 2020, from www.jstor.org/stable/10.1086/341439.

Waldmann, E., 1980, 'Ecology of the nutrition of the Bapedi, Sekhukhuneland', J.R.K. Robson (ed.), Food, ecology and culture: Readings into the anthropology of dietary practices, Gordon and Breach Science Publishers, New York, NY. 